\title{
Difficulties Analysis of Science Teachers in Mastery Photosynthetic Learning Materials at Junior High Schools in Medan Deli District
}

\author{
Mei Sarah ${ }^{1}$, Herbert Sipahutar ${ }^{2 *}$, Fauziyah Harahap ${ }^{2}$ \\ ${ }^{1}$ Biology Education Student, Postgraduate Program, Universitas Negeri Medan, Indonesia \\ ${ }^{2}$ Biology Department Lecturer, Universitas Negeri Medan, Indonesia
}

*Corresponding Author: Herbert Sipahutar, Biology Department Lecturer, Universitas Negeri Medan, Indonesia

\begin{abstract}
This research was conducted in Medan Deli District Junior High Schools which aimed to find out the level of difficulty of science teachers (1) in Medan Deli District Junior High School; (2) those that has been certified; (3) those that not yet certified; (4) those who teach in public schools; and (5) those who teach in private schools. The research sample consisted of 40 science teachers from a population of 40 science teachers in whole 12 (twelve) Medan Deli Junior High Schools. The research instruments in the form of nontest are documentations, questionnaires, observation sheets and interviews. The results showed the level of difficulty of science teachers; (1) in Medan Deli District Junior High School were low (47.64\%); (2) those that has been certified were classified as low (41.30\%); (3) those that not yet certified were classified as high (71.71\%); (4) those who teach in public schools were classified as low (41.43\%); (5) those who teach in private schools were classified as moderate (64.81\%). The results of this study imply the importance of overcoming the difficulties faced by teachers by providing training as well as by communication between teachers in the field of science studies in teacher discussion forums (Musyawarah Guru Mata Pelajaran / MGMP) and the need to facilitate schools with facilities and infrastructures that support the successful learning activities.
\end{abstract}

Keywords: Teacher Difficulty Analysis, Learning Materials, Photosynthesis.

\section{INTRODUCTION}

The last Curriculum2006 or better known as KTSP (Kurikulum Tingkat Satuan Pendidikan), based on the results of the study there are still many problems found and are the background of the government in developing the Curriculum 2013. The Laws of Educational and Cultural Ministry(Kemendikbud) No. 68 of 2013 concerning the Basic Framework and Structure of the Junior High School Curriculum (in Kemendikbud, 2013) are as follows: (1) The Curriculum 2013 was developed on the theory of "standard-based education", and the theory of competency-based curriculum.Education based on standards stipulates the existence of national standards as a minimum quality of citizens which are detailed as content standards, process standards, competency standards, completeness standards, teacher and education staff standards, facilities and infrastructure standards, management standards, financing standards and education assessment standards. The competency-based curriculum is designed to provide the broadest learning experience for students in developing the ability to behave, be knowledgeable, be skilled and act. (2) The Curriculum 2013 adheres to the teaching conducted by the teacher (taught curriculum) in the form of a process that is developed in the form of learning activities at school, class and community. Direct learning experience (learned curriculum) in accordance with background, characteristics, according to the basic abilities of students.

In science learning, the interaction between students and their environment is something that cannot be ruled out. Other things that teachers must realize in developing science learning include knowledge, the investigation / exploration process, and values that can be applied and developed in real life. Improving the quality of education is related to all components of education, namely students, educators, curriculum also facilities that interact well with each other in learning science. Factors that limitteaching photosynthesis include: lack of teacher expertise in the content of this field, lack of experience in the suitability of teaching activities; lack of infrastructure and curriculum materials also lack of teaching time (Keles \& Kafeli, 2010).

According to Hamalik (2011), mastery of learning tools is the ability of teachers to design, arrange 
and implement everything that will be used in the learning process related to the material, use learning media, find appropriate learning resources and be able to make assessment instruments. According to Harjanto (2011) mastery in delivering material can be interpreted as an understanding that is not only for remembering but can also re-express the contents of the material in its own language without changing its meaning.

According to Hamka (2013), mastery of learning tools by teachers also has an impact by making it easier for students to master learning material. According to Iyanda (2014) the instruments of mastery indicator are: (1) able to draw up a plan for implementing learning according to the principles of its preparation and development; (2) able to implement coherent and systematic learning referring to the lesson plan; (3) able to design assessment instruments as benchmarks for the achievement of learning competencies.

The learning activity of the basic competence of photosynthesis in junior high school education is taught by grade VII teachers, in terms of mastering the basic concepts that support photosynthesis learning, teachers still experience difficulties in mastering and delivering material to students. Research results by Sridevi (2014) the difficulty of teachers in planning learning with the category of not good / bad 73.62\% while the evaluation aspect in the category is not good / bad with a percentage of $53.54 \%$.

The main difficulty faced by the teacher is related to photosynthesis material, the process of photosynthesis to the formation of simple compounds. The next difficulty is the lack of tools to observe the process of photosynthesis which is abstract and difficult to understand so as to provide an opportunity for misconceptions. The concept of photosynthesis is very important in learning science because it is key in the life process and the basis of overall plant function (Anderson, 2013).

The teacher as a strategic component in the learning process has the potential to be a weak point or a major obstacle to the competency-based learning process when unable to reach professional maturity. To provide good mastery and meaningfulness about the concept of photosynthesis to students, teachers are required to be able to do true and appropriate learning in order to achieve good understanding.

Analysis difficulty of photosynthesis learning activity is intended to identify the problems faced by teachers in the field in conducting photosynthesis learning activity and solutions to overcome them, because photosynthesis is an abstract concept, difficult, important, and its application is closely related to everyday life. This research is interesting to do because it can determine the level of difficulty of teachers in mastering the learning tools of photosynthesis material.

\section{METHODS}

\subsection{Location, Population and Sample}

This research was conducted in Medan Deli District Junior High Schools. The study was conducted from July to September 2019. The population of this study was all of the $7^{\text {th }}$ Grade Science Teachers in Medan Deli District Junior High Schools as many as 40 teachers from 12 Junior High Schools. The research sample consisted of 40 science teachers of $7^{\text {th }}$ grade from 12 Junior High Schools. Sampling was done by total sampling technique.

\subsection{Research Type}

This study used descriptive research type which was supported by data obtained through document studies and field research. The study of documents was to examine and study various literatures (references) that were closely related to the problem to be studied. While field research, researchers directly went to the field or conducted at school through documentation, observation, questionnaires and interviews in order to obtain accurate and clear data.

\subsection{Research Instruments and Data Analysis Techniques}

This study used non-test instruments in the form of a questionnaire by considering various factors, namely time, the amount of data that was quite a lot and geographically dispersed. The technique used was statistical analysis, using the statistical formula (percentage). The results of calculations in the form of percentages were interpreted by the Table of criteria for the level of difficulties, then interpreted with sentences that were qualitative.

\section{RESUlTS AND DisCUSSIONS}

\subsection{Results}

\subsubsection{Difficulties Analysis of Science Teachers in Photosynthetic Learning Activities}

Description of research data using a questionnaire about learning devices mastery for science teachers in Medan Deli District Junior High Schools in learning photosynthesis can be presented in Table 1. 
Difficulties Analysis of Science Teachers in Mastery Photosynthetic Learning Materials at Junior High Schools in Medan Deli District

Table1: The Difficulty Level for Science Teachers in Medan Deli District Junior High Schools in Learning Photosynthesis Material

\begin{tabular}{|l|l|l|l|l|l|l|}
\hline No & Aspects & Total Number of Teachers & $\mathbf{n}$ & $\mathbf{N}$ & $\mathbf{P}(\boldsymbol{\%})$ & Categories \\
\hline 1 & Lesson Plan & 40 & 1104 & 1920 & 57.50 & Moderate \\
\hline 2 & Learning Activities & 40 & 3826 & 6240 & 61.31 & Moderate \\
\hline 3 & Learning Evaluation & 40 & 860 & 1440 & 59.72 & Moderate \\
\hline & Sum & & $\mathbf{4 5 7 4}$ & $\mathbf{9 6 0 0}$ & $\mathbf{4 7 . 6 4}$ & Moderate \\
\hline
\end{tabular}

Note: $\mathrm{n}=$ the score obtained by the respondent; $\mathrm{N}=$ the score that must be obtained by the respondent; $\mathrm{P}=$ difficulty percentage.

Based on research data in Table 1 by using a questionnaire for the teachers which preparing lesson plan on photosynthesis material at obtained $57.50 \%$ with a moderate category of difficulty level. The results of research for science teachers in carrying out photosynthesis learning activities obtained $61.31 \%$ included in moderate category of difficulty level. In learning evaluation based on the results of the study using a questionnaire obtained 59.72\% included in the moderate category of difficulty level.

Based on the results of the research questionnaire data interpretation of the three aspects mentioned above, it can be concluded that the level of difficulty of science teachers in Medan Deli District Junior High Schools in carrying out learning in photosynthesis material was classified as moderate with an average percentage of $47.64 \%$. For more details, the following graph was presented the difficulty level of teachers from the three aspects of research presented in Figure 1.

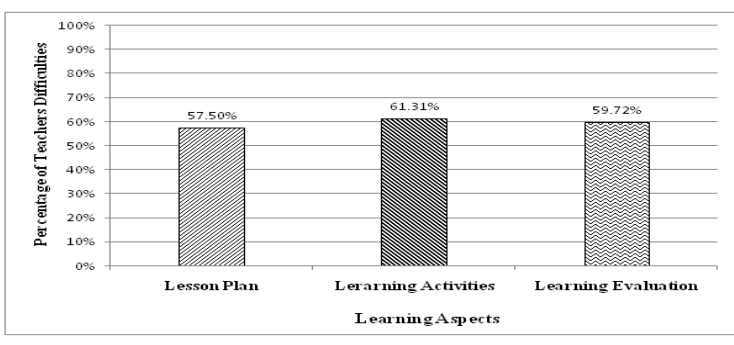

Figure1: The Level of Difficulty of Science Teachers in Terms of Three Learning Aspects

\subsubsection{Difficulties Analysis of Science Teachers That Has Been Certified}

Description of research data using a questionnaire about learning devices mastery for science teachers in Medan Deli District Junior High Schools in learning photosynthesis can be presented in Table 2.

Table2: The Difficulty Level for Science Teachers That Has Been Certified in Learning Photosynthesis Material

\begin{tabular}{|l|l|l|l|l|l|l|}
\hline No & Aspects & Total Number of Teachers & $\mathbf{n}$ & $\mathbf{N}$ & $\mathbf{P}(\boldsymbol{\%})$ & Categories \\
\hline 1 & Lesson Plan & 15 & 300 & 720 & 41.67 & Low \\
\hline 2 & Learning Activities & 15 & 971 & 2340 & 41.50 & Low \\
\hline 3 & Learning Evaluation & 15 & 216 & 540 & 40 & Low \\
\hline & Sum & & $\mathbf{1 4 8 7}$ & $\mathbf{3 6 0 0}$ & $\mathbf{4 1 . 3 0}$ & Low \\
\hline
\end{tabular}

Note: $\mathrm{n}=$ the score obtained by the respondent; $\mathrm{N}=$ the score that must be obtained by the respondent; $\mathrm{P}=$ difficulty percentage.

Based on research data in Table 2 by using a questionnaire for the teachers which preparing lesson plan on photosynthesis material at obtained $41.67 \%$ with a low category of difficulty level. The results of research for science teachers in carrying out photosynthesis learning activities obtained $41.50 \%$ included in the low category of difficulty level. In learning evaluation based on the results of the study using a questionnaire obtained $40 \%$ included in the low category of difficulty level.

Based on the results of the research questionnaire data interpretation for science teachers who have been certified of the three aspects: lesson plan, learning activities and learning evaluation, an average percentage of difficulties was obtained by $41.30 \%$ with a low category. For more details, the following graph was presented the difficulty level of teachers from the three aspects of research presented in Figure 2.

\subsubsection{Difficulties Analysis of Science Teachers That Not Yet Certified}

Description of research data using a questionnaire about learning devices mastery for science teachers in Medan Deli District Junior High Schools in learning photosynthesis can be presented in Table 3.

Table3: The Difficulty Level for Science Teachers That Not Yet Certified in Learning Photosynthesis Material

\begin{tabular}{|l|l|l|l|l|l|l|}
\hline No & Aspects & Total Number of Teachers & $\mathbf{n}$ & $\mathbf{N}$ & $\mathbf{P}(\%)$ & Categories \\
\hline
\end{tabular}


Difficulties Analysis of Science Teachers in Mastery Photosynthetic Learning Materials at Junior High Schools in Medan Deli District

\begin{tabular}{|l|l|l|l|l|l|l|}
\hline 1 & Lesson Plan & 25 & 804 & 1200 & 67 & Moderate \\
\hline 2 & Learning Activities & 25 & 2855 & 3900 & 73.21 & High \\
\hline 3 & Learning Evaluation & 25 & 644 & 900 & 71.56 & High \\
\hline & Sum & & $\mathbf{4 3 0 3}$ & $\mathbf{6 0 0 0}$ & $\mathbf{7 1 . 7 1}$ & High \\
\hline
\end{tabular}

Note: $\mathrm{n}=$ the score obtained by the respondent; $\mathrm{N}=$ the score that must be obtained by the respondent; $\mathrm{P}=$ difficulty percentage.

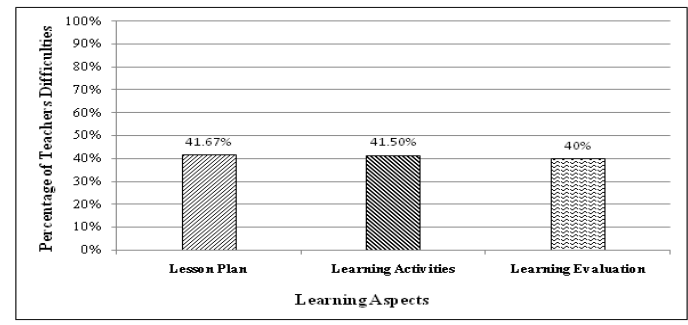

Figure2: The Level of Difficulty of Science Teachers That Has Been Certifiedin Terms of Three Learning Aspects

Based on research data in Table 3 by using a questionnaire for the teachers which preparing lesson plan on photosynthesis material at obtained $67 \%$ with a moderate category of difficulty level. The results of research for science teachers in carrying out photosynthesis learning activities obtained $73.21 \%$ included in the high category of difficulty level. In learning evaluation based on the results of the study using a questionnaire obtained $71.56 \%$ included in the high category of difficulty level.

Based on the results of the research questionnaire data interpretation for science teachers who not yet certified of the three aspects: lesson plan, learning activities and learning evaluation, an average percentage of difficulties was obtained by $71.71 \%$ with a high category. For more details, the following graph was presented the difficulty level of teachers from the three aspects of research presented in Figure 3.

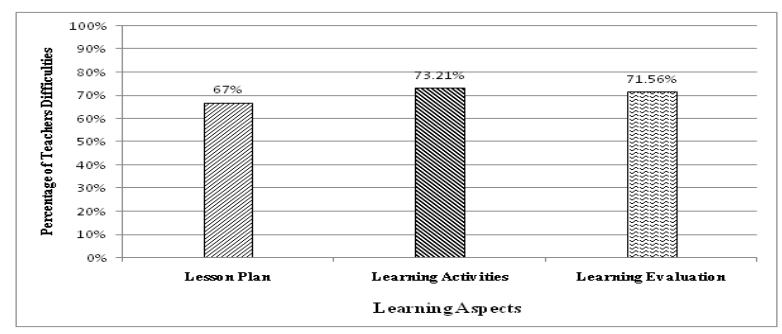

Figure3: The Level of Difficulty of Science Teachers That Not Yet Certified in Terms of Three Learning Aspects

\subsection{Discussions}

\subsubsection{The Level of Difficulty of Science Teachers in Implementing Learning on Photosynthesis Material in Medan Deli District Junior High Schools}

Based on the results of research questionnaire analysis of the difficulties of science teachers in implementing photosynthesis topic in Medan Deli District Junior High Schools, it was found that the difficulty in preparing lesson plans was the lowest (57.50\%) compared to aspects of learning activities $(61.31 \%)$ and learning evaluation (59.72\%). The results illustrated that basically science teachers already had skills in preparing lesson plan that will be used as guidelines in implementing learning activities in the classroom. There were several obstacles faced by science teachers in arranging the lesson plan: the time allocation, determine learning methods that were appropriate to the material and the selection of instructional media including IT.

The results of the questionnaire data interpretation were in accordance with the opinion of Djamarah (1996) "The difficulties commonly faced by teachers were: (1) what competencies were to be achieved, (2) what materials were needed, (3) methods, which tools should be used, (4) what procedures will be taken to conduct the assessment. Tambunan (2011) said that in general, teachers did not understand deeply the basics of knowledge needed to explain photosynthetic material while at the same time finding the right way of learning, the difficulty in obtaining teaching material resources, application of lesson plan that were not appropriate.

The level of difficulty of teachers in terms of learning activities was categorized as moderate, but of the three aspects of teacher difficulties in carrying out learning photosynthesis material, aspects of learning activities were the highest level among the two others. The difficulty of teachers in the aspects of implementing photosynthesis learning activities mainly lied in the inability of teachers to 
implement varied learning methods, lack of use of instructional media to assist teachers in presenting material to students, teacher education background, lack of teacher experience and limited facilities and infrastructure.

The findings found in this study, there were some teachers who did not use any media at all in carrying out the learning activities, so the material was delivered to students verbally by the lecture method. Practical activities related to learning material were also not carried out due to limited facilities and infrastructure. Researchers saw in some schools, the absence of laboratories and even the tools used to facilitate practicum activities do not exist.

The lack of use of instructional media used by teachers to carry out learning activities was also caused by the availability of inadequate facilities and infrastructure, where from the results of observations made by researchers there were several schools that had a limited number of projector and there were some schools that did not have projector, so they cannot facilitate all teachers who want to use the media (especially power points) in learning activities. The availability of facilities and infrastructure greatly supported the creation of effective learning activities. The current condition showed that there were still any gaps in terms of the completeness of inter-school facilities and infrastructure both in terms of quality and quantity even between schools in one District. This limitation was one of the causes of the lack of use of instructional media used by teachers to facilitate learning activities.

As in the opinion of Mulyasa (2009), learning resource facilities were selected and used in the learning process if appropriate will support the achievement of the desired competencies. Saragih (2008) stated that learning media occupies an important position as one of the components of the learning system. Without the media, the communication process in learning cannot take place optimally. During this time most teachers taught the topic of photosynthesis only by lecturing or reading assignments and summarizing a reading material related to the material (Kunandar, 2011). Recent research showed that science teachers recognized the need to teach photosynthesis, but little was done. According to Hidayati (2016), that one of the factors limiting the teaching of photosynthesis was the lack of teacher expertise in the content of this field due to not mastering the basic concepts that underlie photosynthetic material. Suprayitni (2013) also emphasized the difficulties faced by teachers in carrying out their duties were; (1) lack of experiment, teaching aids and media; (2) lack of handbooks; (3) lack of motivation from students; (4) lack of administrative support. From the results of this study indicated that the difficulty of science teachers in the learning process was the lack of understanding of photosynthesis, time management, the provision of tools, materials that support photosynthesis learning.

For the level of difficulty of science teachers in the evaluation aspect with a moderate level of difficulty. This illustrated that in terms of learning evaluation, half of the teacher already had competence and understood the flow of making instruments that will be used to test the completeness of the learning implementation. Some positive things that had been mastered by teachers in relation to making an assessment instrument between questions about the suitability of the questions and indicators of competency achievement, the distribution of questions in terms of the level of difficulty including processing and interpreting student learning outcomes. However, the results of the respondents' answers also revealed some weaknesses and difficulties experienced by the teacher, especially in making attitudes and portfolio grades.

\section{Conclusions}

Based on data analysis for the difficulties of science teachers who have been certified in implementing science learning photosynthetic material in general, concluded to the low category with an average of (41.30\%). This stated that teachers who have been certified did not experience difficulties in the aspects of lesson plan, learning activities and learning evaluation. Things that needed to be considered for teachers that has been certified in implementing learning activities was the availability of facilities to support the successful learning activities. Teachers who have been certified were experiencing difficulties in the aspects of implementing learning activities due to limited infrastructure and facilities in each school.

Based on data analysis for the difficulties of science teachers who have not been certified in implementing science learning photosynthetic material in general, concluded to the high category with an average of (71.71\%). The level of difficulty of science teachers who have been certified in the implementation of learning was relatively low, while the difficulty level of teachers who have not been certified was high.

Compared to teachers who have been certified, teachers who have not been certified have more difficulties in implementation of learning activities. This was consistent with Azwar's (2015) research that there was a significant difference between the performance of teachers that have not yet certified 
and those who have been certified at SMP Negeri 2 Banda Aceh. The performance of pedagogical competencies and professional teachers who have been certified was better than teachers who have not been certified. Kartowagiran (2015) stated that teacher performance before certification has not been maximally started from the preparation of lesson plans, selection of methods, learning and evaluation of learning compared to teachers who have been certified. Suprayitno (2013) stated that there was an influence of teacher certification on performance in improving the quality of learning. Murwati (2013) also stated that there was an effect of certification on the quality of learning.

\section{REFERENCES}

[1] Anderson, C.W., Sheldon, T.H., Dubay, J. (2013). "The effect of instruction on college non majors' conception of respiration and photosynthesis". Journal of Research in Science Teaching, 27 (8): 761-776.

[2] Azwar, K. 2015.Pengaruh Sertifikasi dan Kinerja Guru Terhadap Peningkatan Hasil Belajar Siswa SMP Negeri 2 Banda Aceh. Thesis, Univeristas Syiah Kuala. Banda Aceh.

[3] Djamarah. 1996. Strategi Belajar Mengajar. Jakarta: Departeman Pendidikan Nasional

[4] Hamalik. 2011. Kurikulum dan Pembelajaran. Jakarta: Bumi Aksara,

[5] Hamka, L. (2013). Analisis Kompetensi Profesional Guru Biologi SMP Negeri di Kota Makasar. Jurnal Bionature, 14 (1):25-32.

[6] Harjanto. 2011. Perencanaan Pengajaran. Jakarta: Rineka Cipta.

[7] Hidayati, N. 2016. Pembelajaran Berorientasi Standar Proses Pada Materi Fotosintesis untuk meningkatkan Keterampilan Proses dan Hasil Belajar Siswa Kelas VIII SMP Negeri 2 Dawarblandong. Pansa -e jurnal: Pendidikan Sains

[8] Iyanda, F. 2014. Identifikasi Miskonsepsi Guru Biologi SMA Kelas XI IPA. Jurnal EduBio Tropika, 2 (1): 187-250.

[9] Kartowagiran, B. 2015. Kinerja Guru Profesional (Guru Pasca Sertifikasi). Tesis. Universitas Negeri Yogjakarta.

[10] Keles, E. \& Kefeli, P. 2010. Determination Of Student Misconceptions in "Photosynthesis and Respirations" Unit and Correcting Them With The Help Of Cai Material. Journal of Procedia Social and Behavioral Sciences, 2 (1): 3111-3118.

[11] Kunandar. 2011. Guru Profesional, Implementasi KTSP dan Sukses dalam Sertifikasi Guru. Jakarta: Rajawali Press.

[12] Mulyasa. 2009. Kurikulum Tingkat Satuan Pendidikan. Bandung: PT. Remaja Rosdakarya.

[13] Murwati, H. (2013). Pengaruh sertifikasi Profesi Guru Terhadap Motivasi Kerja dan Kinerja Guru di SMK Negeri Se- Surakarta. Jurnal Pendidikan dan 1(1):1-10

[14] Saragih. 2008. Kompetensi Minimal Seorang Guru Dalam Mengajar. Jurnal Tabularasa PPS Unimed (5): 1.

[15] Sridevi, M. 2014. Kinerja Guru SMP Se-Kabupaten Lombok barat. Jurnal Pendidikan IPA UPI, 6 (3): 273-284.

[16] Suprayitno. (2013). Pengaruh Sertifikasi Terhadap Kinerja Guru dengan Supervisi Akademik dan Internal Locus of Control. Jurnal pendidikan. 13 (1):1-7

\section{AUTHORS' BIOGRAPHY}

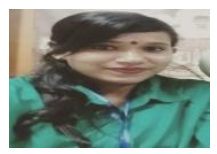

Mei Sarah, S.Pd, is a Biology Education Postgraduate student at Postgraduate Program of Universitas Negeri Medan (State University of Medan), Medan, North Sumatera, Post code 20221, Indonesia

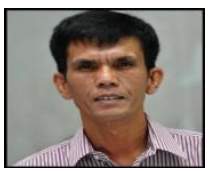

Prof. Dr. Herbert Sipahutar, M.Sc, is a Lecturer at Graduate and Postgraduate Program of Universitas Negeri Medan (State University of Medan), Medan, North Sumatera, Post code 20221, Indonesia.

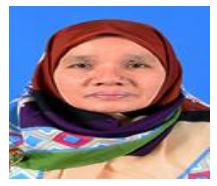

Dr. Fauziyah Harahap, M.Si, is a Lecturer at Graduate and Postgraduate Program of Universitas Negeri Medan (State University of Medan), Medan, North Sumatera, Post code 20221, Indonesia

Citation: Herbert Sipahutar, et.al. Difficulties Analysis of Science Teachers in Mastery Photosynthetic Learning Materials at Junior High Schools in Medan Deli District". International Journal of Humanities Social Sciences and Education (IJHSSE), vol. 6, no.12, 2019, pp. 147-152. doi: http://dx.doi.org/10.20431/23 49-0381.0612013.

Copyright: () 2019 Authors. This is an open-access article distributed under the terms of the Creative Commons Attribution License, which permits unrestricted use, distribution, and reproduction in any medium, provided the original author and source are credited. 